\title{
Performing the Literal: Translating Chekhov's Seagull for the Stage
}

Geraldine Brodie

\section{Introduction: Personal perspectives of interpretation}

As the translator of twelve Russian plays over a twenty-five-year period, Helen Rappaport has charted "the appearance, disappearance and all too occasional re-emergence of the name of the literal translator in press reviews and theatre programmes" (2007: 75). Rappaport has, however, emerged sufficiently to point out the lack of awareness of the role of literal translators and the function of their output $(2001,2007)$. This chapter seeks to capture literal translation in the spotlight by comparing two productions based on Rappaport's work on Anton Chekhov's 1896 play The Seagull. Chekhov's work is not a new topic for investigation, and there is plenty of opportunity to examine his work in translation and performance. As Gunilla Anderman observes, the dramatic work of this Russian author (1860-1904) is so frequently performed on the English stage that “'English Chekhov' has even been turned into an export product" with English-language versions staged overseas, including in Russia (2005: 129-130). Furthermore, Chekhov's works “continue to be translated into the many languages of the world" (Apollonio and Brintlinger 2012: 1), with production of his plays “an international industry” (Marsh 2010a: 112).

Chekhov's writing has been extensively examined from perspectives of literature, drama, history, theatre and performance studies, translation and adaptation; investigation of the "wide geographical landscape of Chekhovian influences" extends to intermedial mutations and paratext (Clayton and Meerzon 2013: 1-11). Even so, case studies "may point to the need for a new theory in areas that have not received sufficient scholarly attention" (Saldanha and O'Brien 2013: 210). The function of the literal translation, and its interaction with the source language playtext and target language performance text, is overlooked and understudied by 
practitioners, audiences and academics alike. The general dearth of information on this topic renders large-scale investigation problematic. A case study, however, permits a focus on a "unique unit of investigation" with an "emphasis on contextualization and a real-life setting" and can be distinguished from "textual analysis, where there is a clearer boundary between the object of enquiry and its context" (Saldanha and O'Brien 2013: 207). Rappaport's literal translation and its two offspring present a neatly-defined corpus for an exploration of the phenomenon of literal translation within the theatrical field, eschewing textual comparison for the systematic analysis of a wider set of data. Documenting the process of this enquiry also generates reflection on the nature of case study research.

As Stake highlights, the uniqueness of each case study is necessarily deliberate, as "each researcher's style and curiosity will be unique in some ways" (1995: 135). My desire to examine the role of literal translation in productions of The Seagull arose from my observation that the Royal Court Theatre in London made an exception to its usual theatrical translation practice in its 2007 production of Chekhov's play. This production, the last to be directed by Ian Rickson before leaving his position as artistic director of the theatre, used a text commissioned from the playwright and translator from French and German, Christopher Hampton, based on a "heavily annotated" literal translation by Vera Liber (Hampton 2007: 3). I was intrigued to investigate why the Royal Court had departed from its standard practice of commissioning direct translations for performance from language specialists, particularly in view of the policy stipulated by the literary manager, Christopher Campbell, that the theatre does not employ literal translators because "we are encouraging translators to engage with the language directly" (quoted in Trencsényi 2015: 55).

A version of The Seagull written by the playwright and translator from French, Martin Crimp, had opened at the Royal National Theatre (which generally refers to itself as the "National Theatre," omitting its Royal title) in London only seven months previously, 
directed by Katie Mitchell. Crimp and Mitchell are regular co-collaborators who also create work, together and separately, for the Royal Court. My comparison of brief selections of the published playtexts by Crimp and Hampton demonstrated Hampton's closer adherence to some degree of Russian form in contrast with Crimp's de-exoticized text (Brodie 2016b: 9293). I hoped that a further case study investigating the two performance texts, their literal translation sources and their staged productions would shed light on the role of the literal translation in the creation of a performance text and on theatrical translation policies more generally. This case study therefore reflects the topics, debates and material that I engage with in the ongoing progression of my research, rather than forming a discrete unit of a larger research enterprise. Furthermore, the scope of this volume entailed limiting the length of the case study report, which inevitably influences (and restricts) research decisions.

At the early stages of preparation, however, two elements intervened to alter the corpus of the study. The first was a difficulty in obtaining Liber's literal translation. This was not unexpected; literal translations are not published, and their readership is restricted to a handful of theatre practitioners: the literary manager, the director and the adapting playwright. The Royal Court is a high-profile, relatively well-resourced but space-restricted organization that, in common with most other theatres, does not maintain systematic physical archives on the premises. The theatre and performance collections at the Victoria and Albert Museum in London "include many archives from performing arts companies and other organisations, as well as from individuals such as performers, stage designers and private collectors" (Victoria and Albert Museum 2016). Among this material is the combined archive of the English Stage Company and the Royal Court Theatre (the building in which the company performs), with 3,854 entries, of which 187 relate to the literary department. Such records are, however, dependent on the retention practices of individual entities and the personnel charged with archival submission. Currently, the only item in this archive relating 
to the 2007 production of The Seagull is a publicity poster, although further material may make its way in due course. Furthermore, the copyright of literal translations usually vests in the translator, with the commissioning theatre retaining a licence to use the translation for production. If there is no stringent archive policy and designated archivist (and even when there is), documents can be overlooked for retention, especially where complicated ownership provisions apply. Paucity of archives is common in historical theatre research, but can sometimes be overcome through personal enquiry of relevant contacts, especially with more recent productions. Before I had exhausted this route of investigation, however, a second discovery prompted me to change tack.

On 17 October 2015 I spent twelve hours at the Chichester Festival Theatre attending consecutive performances of three Chekhov plays in English versions by the playwright David Hare, presented as a triple bill under the title "Young Chekhov: The Birth of a Genius." The third of these performances was The Seagull. I know from previous examinations of Hare's method of working from a literal translation that he takes pains to credit the translator (Brodie 2012: 67). Both the programme (Chichester Festival Theatre 2015: np) and the published text for this production (Hare 2015: 255) acknowledge the literal translation by Helen Rappaport, who was also credited by Martin Crimp for her "literal translation and critical commentary" for his version of The Seagull (2006: np). The National Theatre maintains its own archive, curated by a professional archivist and dedicated team of assistants. When the Chichester production transferred to the National Theatre in 2016, my enquiry to the archival team established that not only was Rappaport's translation included and available for viewing, but also that this translation had been used for both Hare's and Crimp's versions.

This information was striking enough to merit the variation of the corpus for my case study. Firstly, Crimp and Hare have significantly differing approaches to their theatrical writing, 
including their construction of versions from the work of other playwrights. Secondly, these two playwrights might be expected to command audiences with varied perspectives; Hare has a substantially larger body of original plays and adaptations that have been staged at the National--28 between 1971 and 2016--whereas only four of Crimp's works have received production--between 2004 and 2009--although these also include versions and original plays, such as the ground-breaking Attempts on her Life, revived in 2007 in a production directed by Katie Mitchell (National Theatre Archive 2016). Thirdly, high-profile productions such as these two versions of The Seagull would generally be resourced sufficiently to enable the commissioning of a new literal translation. My discussions with writers working from literal translations indicate that they generally prefer a literal translator to be available for dramaturgical consultation (Brodie 2013: 125); there is also a widely-held view that translations date.

And yet Hare had been prepared to use a translation commissioned for an earlier, and very different, production. The fact that this one translation provided the source for two productions, replicating the original text, was an intriguing feature, which I investigate more fully in this case study. Based on this discovery, my detailed objectives changed, since I would no longer be able to establish why the Royal Court had elected to depart from its usual translation policy. On the other hand, the circumstances provided a unique opportunity to investigate the role of a literal translation in the trajectory of a source text from its inception to production in another language.

\section{The Seagull: Contextualizing the new}

When first written, The Seagull was "unlike anything seen on the stage before" (Merlin 2003: 10). After an unsuccessful premiere at the Aleksandrinsky Theatre in St. Petersburg in 1896, the play was revived to critical and public acclaim two years later at the Moscow Arts 
Theatre under the direction of Konstantin Stanislavski, "the most influential theorist of modern acting" (Marsh 2010b: 572). The combination of a revolutionary "system" of naturalistic acting and authentically detailed stage sets, with Chekhov's realistic dialogue and portrayal of contemporary life has since been credited with radically changing European approaches to drama, from playwriting to directing to acting to audiences. Naturalism continues to influence theatrical presentation on contemporary stages from a range of aspects, including translation and the performability of a text. Lucy Jackson, for example, describes the pressure from actors in the rehearsal room to domesticate the language of a translated script, resulting from their training in "rigorous and psychologically rooted naturalism" (Jackson 2017: 110). The influential nature of Chekhov's play renders it particularly appropriate for a case study, according to Robert K. Yin's first criterion for what makes an exemplary case study: significance from the point of view of public interest and theoretical importance (2009: 185). Stuart Young notes that the "remarkably" large number of translations of Chekhov's plays is one of the "most intriguing aspects of the English theatre's love affair" with the playwright, creating an "English Chekhov tradition" (2009: 327-28). The two versions in this case study bookend nine different productions of The Seagull in London during the ten years from 2006 to 2016, exemplifying the quantity and range of approaches within this "tradition".

Furthermore, both productions were staged at the National Theatre. This organization can be seen as the pivot of English national theatrical activity; it receives the largest amount of public funding among British theatrical institutions ${ }^{\mathrm{i}}$ with a wide remit to serve the national artistic interest while also contributing to the advancement of the arts, thus combining the canonical with the experimental. The concept of a national theatre is itself open to question: Nadine Holdsworth critiques the traditional model of national theatre, querying whether any single theatre "can legitimately claim to serve as a theatre of and for the nation as a whole" 
(2010: 34). I would argue nevertheless that both its geographical location and its virtual presence at the centre of a large network of theatre practitioners render the National Theatre an influential and significant site of research for case study purposes.

The resources of this institution also assist in meeting Yin's second case study criterion, that the "case study must be complete" with regard to defined boundaries, the collection of evidence and the ability to reach a conclusion from the research (2009: 186-87). The versions by Crimp and Hare have both been published (Crimp 2006; Hare 2015); the literal translation is available for viewing in the National Theatre archives, as are digital recordings of both productions; the productions have been staged and completed; and reception in the form of critical reviews has been recorded and collected in the authoritative journal Theatre Record. Evidence is therefore available for contained case research to be conducted according to Yin's principles. Nevertheless, all three texts may reappear at some point which would make an extension or re-examination of the case study possible. Rappaport's literal translations, as this case study demonstrates, are reused and therefore this text could be used for further versions with different outcomes. The National Theatre production of Hare's version was already a revival of the Chichester Festival Theatre production, indicating that this production itself could move to further venues, or that the text could be used again for a new production. Crimp's version has been translated into Danish by Niels Brunse and was staged at Det Kongelige Teater, Copenhagen, under Katie Mitchell's direction, in 2011, another indication of the iterability of the texts under examination. This phase of the case study can be presented as defined, but it would be impossible to rule out reassessment or revision of the conclusions in the future.

Yin's third criterion for exemplary case study design is that it "must consider alternative perspectives"; these perspectives "may be found in alternative cultural views, different theories, variations among the stakeholders" (2009: 187-88). This case study demonstrates 
how Rappaport's literal translation is approached by two theatre practitioners who vary in their writing style, reputations, audiences, objectives and relationship with translation and adaptation. At the centre of the study, Rappaport's literal translation could be viewed as the embodiment of the "imagined untranslated text in the target language" that Jean Boase-Beier suggests blends into a translated text (2011: 27). As a professional writer, historian and Russianist who began her career as an actor, Rappaport provides texts which couple a superior level of detailed research information targeted for a theatre practitioner with an understanding of theatrical requirements for performable text. In interviews I carried out in 2010-11 (Brodie 2018) with theatre practitioners from various branches of the profession who engaged with translated work--directors, literary managers, translators, writers--Rappaport's literal translations were cited by several individuals as examples of best practice. On reading her translation of The Seagull, I could see why. Her scholarly approach to detail extends to the bibliographic style of referencing; her notes on the text range from listing first performances and publications in Russia and in English translation, along with her identification of the definitive text, "Sobranie Sochinenie v 20 Tomakh [Collected Works in 20 Volumes], Moscow: Nauka, 11978, vols 12-13 (in one)" (Rappaport 2006: 2 [Act 1] $]^{\mathrm{ii}}$ ), to discussions of Chekhov's letters and short stories, Russian theatre conventions, Chekhovian allusions to topical European cultural figures such as Eleonore Duse, Heine, Maupassant and Schumann, and the Russian symbolist movement. Rappaport offers a wealth of contextual information on Chekhov's text while also addressing the nuance of translational choices such as offering "nonsense/rubbish," "philosophize [i.e. pontificate/sound off about things]" and "I feel completely shattered ['broken to pieces']"; these examples are all drawn from one page (Rappaport 2006: 5 [Act 1]). Over the four Acts, Rappaport provides 111 notes, many of them of paragraph length. Rappaport's approach to translation resembles the "thick translation" identified by Kwame Anthony Appiah: "translation that seeks with its 
annotations and its accompanying glosses to locate the text in a rich cultural and linguistic context" (2012: 341). Rappaport's frequent annotations and framing contextual information provide a reminder to her readers of the linguistic process that has taken place. Theo Hermans, developing Appiah's concept, considers that "thick translation contains within it both the acknowledgement of the impossibility of total translation and an unwillingness to appropriate the other through translation even as translation is taking place" (2007: 150). The very different versions of The Seagull created by Crimp and Hare demonstrate how each of these writers responds to Rappaport's representation of the other, adapting her text with the resonances of their own work in writing for theatre.

Crimp and Hare are both perceived as activist theatre makers. Hare (b. 1947), the older of the two by nine years, has been described by the theatre critic Michael Billington as an "astute social commentator...preoccupied by the question of how you live decently inside a corrupt, capitalist world" (2007: 218-20). A prolific playwright, Hare is the author of some 30 stage plays, five of which were included in the top 100 of the National Theatre millennial poll of the greatest plays of the 20th century, a survey conducted amongst over 800 specialists made up of theatre practitioners and arts journalists (National Theatre 2016: 2). Hare has a reputation as a realist playwright, portraying contemporary topics through the metaphor of theatre with dialogue that captures the conversational cadences of the British intelligentsia and ruling classes. "Hare's long-standing commitment to the pure, transparent and direct communication of subject matter in performance" is reflected in the simple clarity of his writing, evidencing his "unease with the inherent artifice of theatre" (Megson and Rebellato 2007: 236). His focus on current issues, along with an accessible written style, draws in large audiences, so that over his 50 year career Hare's reputation has mutated from radical to canonical. 
Hare is an experienced adaptor of plays and screenplays, who embraces the collectivity of theatre-making. Cathy Turner finds in his works a quality "that openly mediates for a whole range of other, distant voices" (2007: 120). Hare acknowledges that his own voice has an affinity for particular playwrights; he perceived a "subtly modern rhetoric" in Chekhov and "slipped straight away into an idiom that seemed appropriate and supple," whereas he had found himself "grasping hopelessly for a surrealist tone beyond [his] reach" in an earlier version of Lorca's The House of Bernarda Alba (Hare 2016: np). By adding The Seagull to his repertoire of versions of classic plays, which already included Chekhov's Platonov and Ivanov, Hare intensifies his affinity with Chekhov, establishing himself as a Chekhov expert. Furthermore, grouping these three early plays into a triple bill permits him to make a claim for a new approach to the Russian playwright. The subtitle of the triple production at Chichester was "the birth of a genius"; for the National Theatre this was removed. Hare writes in his programme notes (slightly adapted from the introduction to the published playtexts), "On the surface, The Seagull is a play about theatre and about writing. But the struggle to create something lasting and worthwhile in life is what really drives the play...We are seeing the birth of the new" (National Theatre 2016: np). This characterizes the tone of his approach in writing his version, and, as I demonstrate in Table 15.2, was also acknowledged in the critical responses to the production.

Making a claim for a new approach to Chekhov was less necessary for Crimp. Described by Martin Middeke as "one of the most versatile, creative and aesthetically prolific and challenging playwrights of our time" (2011: 82), Crimp is a leading proponent of innovative theatre-making, working on a regular basis with directors renowned across Europe for their interventionist approaches to performance, including Thomas Ostermeier and, in the case of this production, Katie Mitchell. Like Hare, Crimp is a subject of academic scrutiny, and also comments on his own work; Aleks Sierz lists 24 interviews with Crimp in the second edition 
of his study of Crimp's theatre (2013: 277-78). The subtitle of Vicky Angelaki's book on Crimp's plays, "making theatre strange," conveys the quality associated with this playwright, and his "purpose of theatrical defamiliarization" (2012: 1).

Moreover, Crimp has an interest in translation and has translated at least eight plays from French, and written versions of at least six further plays that originated in German, ancient Greek and Russian. As I discuss elsewhere, Crimp's overt references to translation in his own work, including his controversial play Attempts on Her Life, "reflect his general textual and thematic shifts and destabilization of societal certainties" while also deconstructing and interrogating the translational act itself, and its role in communication (Brodie 2016a: 236). As a translator and adaptor, Crimp has a tendency to focus on work that might be considered less accessible, either because it is not well known in English (Marivaux's plays, for example), forms part of an experimental genre (as with Ionesco's theatre of the absurd), or is the work of contemporary playwrights such as Bernard-Marie Koltes or Botho Strauss. Crimp's treatments of plays by authors who are well established in the canon, Molière's The Misanthrope and Cruel and Tender, based on Sophocles' Trachiniae, have been radical reworkings, although Crimp would have been working directly from French for the first, and using an intermediary translation for the second. Indeed, Angelaki considers that these plays "depart substantially from the early versions of the texts that inspire them and as such belong to a discussion of Crimp's playwriting canon" (2012: 154).

Crimp's version of The Seagull should therefore be assessed in the context of his other engagements with canonical authors where Crimp offers often startlingly new interpretations that locate his translations and adaptations within the wider sphere of his theatrical writing. My examination of his idiosyncratic employment of the word "sweetheart" across his writing, translation and adaptation (including The Seagull) demonstrates Crimp's authorial voice within his translations and adaptations (Brodie 2016b). Furthermore, Crimp's collaborations 
with Katie Mitchell, a politically committed theatre-maker with an immediate and distinctive directorial voice, also add context to his work on The Seagull, which did not escape the critics, as I show in my discussion of Table 15.2. The alternative approaches of Crimp and Hare to the play they access through Rappaport's literal translation, and the markedly varied responses to those approaches, can be investigated more closely by a detailed comparison of specific aspects of the playtexts and review of their reception.

\section{Translating The Seagull}

In order to meet Yin's fourth criterion for case study design, the most relevant evidence must be "judiciously and effectively presented" to enable an independent judgement to be formed (Yin 2009: 188). The methodologies inherent in conducting even such small-scale research are multiple: defined selection of a corpus, observation of contextual circumstances, literature and archival investigation, comparative reading of the texts, comparative viewing of the productions, and, finally, a reception review by means of targeted documentation. Such activities produce a mass of data to be processed. Yin's recommendation (2009: 188) that the case study report should be restricted to "critical pieces of evidence" echoes Munday's distinction of "certain sensitive or 'critical' points [where] the dynamic cline of language is activated through the translator's interpretation" in order to identify "evaluative style" in translation (Munday 2010: 91). A comparative reading of Crimp's and Hare's versions against Rappaport's literal translation of The Seagull reveals that variances between the two versions are substantial and occur on a line-by-line basis.

Amongst all this data, critical points could draw on a wide range of potential targets, including identifiable style-mannerisms of the two authors; the extent to which the literal translation is retained in the performance text; variances in cuts, omissions and additions; reflection or disregard of the literal translation's annotated contextual information; decisions regarding translation choices and strategies presented by Rappaport in her translation; and, of 
course, the performance modes whereby the different versions were transmitted. How to translate the title of the play, The Seagull, and its symbolic recurrence within the text has been a topic of extensive discussion over the years, which Peace, among others, examines in detail and finds that it causes "some of [Chekhov's] translators embarrassment" (1993: 217). Rappaport provides a long endnote to Act 1 discussing the struggles of the early translator Constance Garnett in translating the Russian chaika into a recognisable form of lake bird which will sound equally plausible when the character Nina uses the word to describe herself. Crimp appears to engage in some depth with this issue, expanding on Garnett's dilemma in his programme note "My mother and Chekhov" (National Theatre 2006: np). This polemic issue presents an opportunity to identify key critical points for comparison. Table 15.1 documents two instances which reveal not only how the performance texts vary in the ways in which they draw on and mould the literal translation for their own purposes, but also how the performances interact with the published text. Hare's conversational style and expansive stage directions draw more on Rappaport's translation than Crimp's staccato, sparely written dialogue, which makes additional cuts. Both writers, however, retain the full "seagull" when Nina describes herself.

Table 15.1: Comparison of Nina's references to herself as a "seagull"

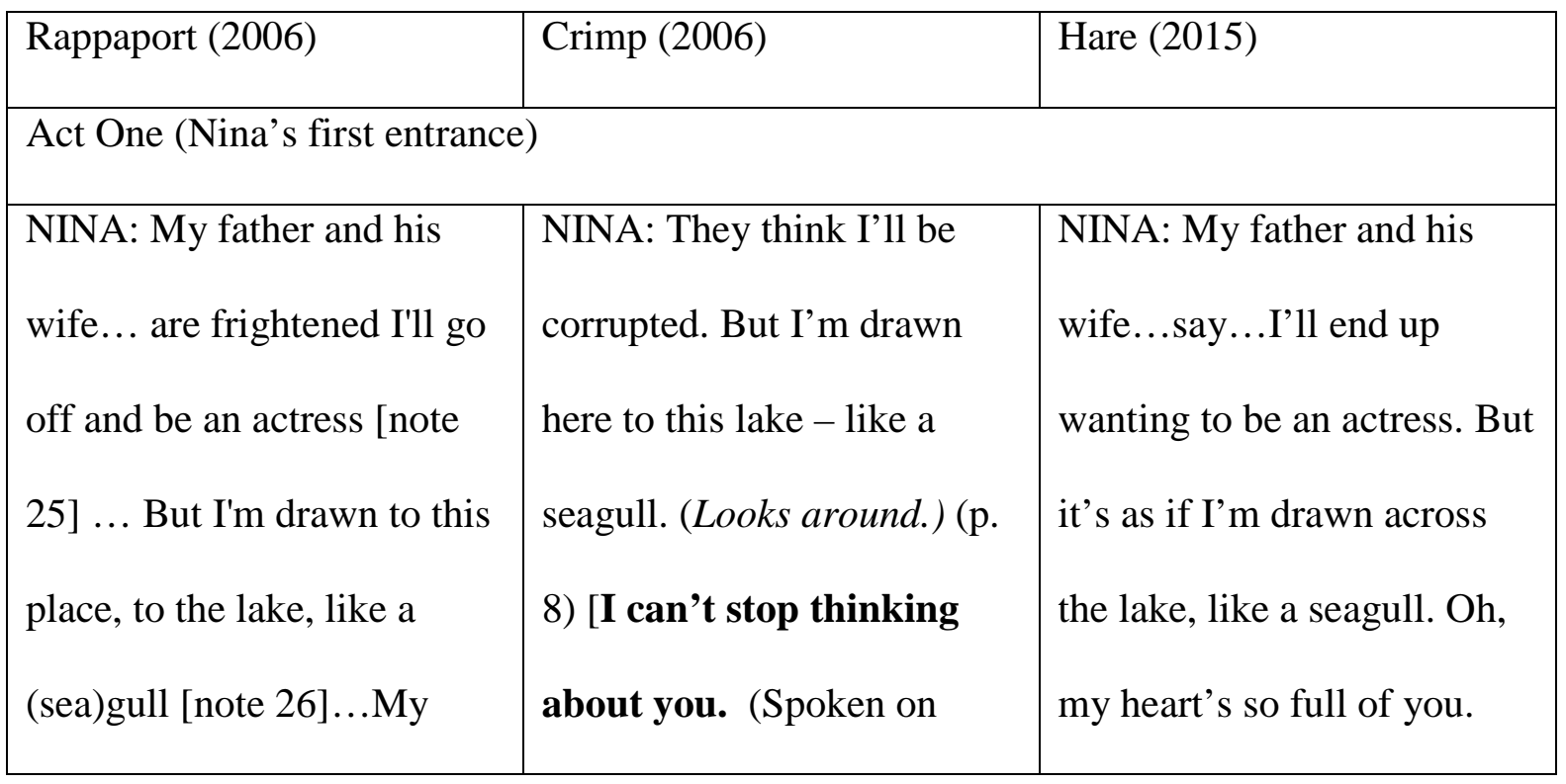




\begin{tabular}{|c|c|c|}
\hline $\begin{array}{l}\text { heart is full of you (Looks } \\
\text { around). (p. } 11 \text { [Act 1]) } \\
\text { [Note 25: Russian idiom for } \\
\text { going on the stage 'to go } \\
\text { among the actresses'] } \\
\text { [Note } 26 \text { : See end note to } \\
\text { this act about the translation } \\
\text { of the Russian chaika.] }\end{array}$ & $\begin{array}{l}\text { stage, but not recorded in the } \\
\text { playtext.)] }\end{array}$ & $\begin{array}{l}\text { She looks round nervously. } \\
\text { (p. 270) }\end{array}$ \\
\hline \multicolumn{3}{|c|}{ Act Four (final scene between Konstantin and Nina) } \\
\hline $\begin{array}{l}\text { NINA: I am--a (sea)gull. } \\
\text { No, that's not it. Remember, } \\
\text { you shot a gull? (p. } 19 \text { [Act } \\
\text { 4]) }\end{array}$ & $\begin{array}{l}\text { NINA: I'm the seagull--is } \\
\text { that right? - no. Remember? } \\
\text { You shot one. (p. } 63 \text { ) }\end{array}$ & $\begin{array}{l}\text { NINA: I am--the seagull. } \\
\text { No, that's not right. You } \\
\text { remember that day when } \\
\text { you shot a gull? (p. } 342 \text { ) }\end{array}$ \\
\hline
\end{tabular}

Evidence consulted for this case study included the performance of the productions that are represented by the published texts. The texts provide merely a partial record of these performances in as much as they cannot capture the tone in which the text is spoken. Furthermore, published stage directions provide only the barest indication of a production's mise en scène, both with regard to the accoutrements of the stage set itself--scenery, effects and properties--and the more expansive reference of the term encompassing "lighting, costuming, and all other related aspects...of the spatio-temporal continuum, including the actions and movements of all the performers" (Postlewait 2010: 396). Any analysis must therefore take account of the non-textual elements, examining the context within which the text is presented, and acknowledging that the published text implicitly represents a wider theatrical environment in which planned (and unplanned) deviations from the written text, 
along with visual, aural and other sensory projections, have a significant impact on the conveyance and reception of a production. Viewing the performances against the texts therefore provides "naturally occurring" empirical materials which themselves constitute the topic of research (Peräkylä and Ruusuvuori 2011: 529); an analysis of the actors’ physical interaction with the text sheds light on the larger issues so that, as Peräkylä and Ruusuvuori point out with regard to the technique of Conversation Analysis, "research that is not explicitly framed around power or status may...bring results that are relevant in discussing these topics" (Peräkylä and Ruusuvuori 2011: 539).

Table 15.1 documents the inclusion of the line (in bold) "I can't stop thinking about you" in the production of the Crimp text, which suggests that a previous cut has been reinstated at a late stage, or that a decision has been made to expand the speech in accordance with the literal translation and performance history. The Russian-speaking playwright Michael Frayn, whose translation of The Seagull is quoted, rather than Crimp's text, by Katie Mitchell as the basis for her directorial decisions for this production (Mitchell 2009: 57-58), interprets this line very similarly to Rappaport as "My heart's full of you” (Frayn 2006: 65). The results of this comparison (and this is one example of a number of cuts and minor additions to Crimp's text in performance) document the interventions in the text beyond Crimp's published version, prompting a discussion of who wields the ultimate power in textual staging decisions, and whether there is a hierarchical textual status in the progression from Chekhov's source text to the performed version.

A systematic comparison and review of the reception of these productions assists in assessing the interplay between the text and performance. Table 15.2 provides extracts from reviews of both productions, assesses the overall positive or negative tone of the review, and documents the number of mentions in each review of the director, writer and Chekhov 
himself. Rappaport is referenced only once, by Michael Arditti in his review for the Sunday Express of Hare's version at Chichester.

Table 15.2: Extracts from reviews of The Seagull in the different versions by Martin Crimp and David Hare

\begin{tabular}{|c|c|c|c|c|c|c|}
\hline Newspaper & \multicolumn{2}{|c|}{$\begin{array}{l}\text { Reviews of Martin } \\
\text { Crimp's version of Anton } \\
\text { Chekhov's The Seagull, } \\
\text { directed by Katie Mitchell } \\
\text { (National Theatre, } 27 \\
\text { June to } 23 \text { September } \\
2006)^{\mathrm{a}} \\
\end{array}$} & \multicolumn{2}{|c|}{$\begin{array}{l}\text { Reviews of David Hare's } \\
\text { season of Young Chekhov: } \\
\text { The Birth of a Genius, } \\
\text { directed by Jonathan Kent } \\
\text { (Chichester Festival } \\
\text { Theatre, } 17 \text { October to } 14 \\
\text { November 2015) }\end{array}$} & \multicolumn{2}{|c|}{$\begin{array}{l}\text { Reviews of David Hare's } \\
\text { season of Young } \\
\text { Chekhov, directed by } \\
\text { Jonathan Kent (National } \\
\text { Theatre, } 3 \text { August to } 3 \\
\text { September 2016) }\end{array}$} \\
\hline \multirow[t]{2}{*}{ Guardian } & \multirow[t]{2}{*}{$\begin{array}{l}\text { Michael } \\
\text { Billington } \\
28 \text { June } \\
2006 \text { (p. } \\
763)\end{array}$} & $\begin{array}{l}\text { Negative: } \\
\text { "director's } \\
\text { theatre at its } \\
\text { most } \\
\text { indulgent" }\end{array}$ & \multirow[t]{2}{*}{$\begin{array}{l}\text { Michael } \\
\text { Billington } \\
19 \text { October } \\
2015 \text { (p. } \\
1043-44)\end{array}$} & $\begin{array}{l}\text { Positive: } \\
\text { "Chekhov } \\
\text { achieves } \\
\text { formal } \\
\text { mastery" }\end{array}$ & \multirow[t]{2}{*}{$\begin{array}{l}\text { Michael } \\
\text { Billingt } \\
\text { on } \\
5 \\
\text { August } \\
2016 \\
\text { (p. } 854)\end{array}$} & $\begin{array}{l}\text { Positive: } \\
\text { Chekhov's } \\
\text { characters } \\
\text { "possess the } \\
\text { endless } \\
\text { susceptibility } \\
\text { to } \\
\text { reinterpretati } \\
\text { on that is the } \\
\text { hallmark of } \\
\text { great drama" }\end{array}$ \\
\hline & & $\begin{array}{l}\text { D: 1, W: 2, C: } \\
5^{\text {d }}\end{array}$ & & $\begin{array}{l}\text { D: 2, W: 2, C: } \\
5\end{array}$ & & $\begin{array}{l}\mathrm{D}: 1, \mathrm{~W}: 2, \mathrm{C}: \\
10\end{array}$ \\
\hline \multirow[t]{2}{*}{ Daily Telegraph } & \multirow[t]{2}{*}{$\begin{array}{l}\text { Dominic } \\
\text { Cavendis } \\
\text { h } 28 \text { June } \\
2006 \text { (p. } \\
763 \text { ) }\end{array}$} & $\begin{array}{l}\text { Positive: "an } \\
\text { ardency, an } \\
\text { urgency and } \\
\text { a clarity" }\end{array}$ & \multirow[t]{2}{*}{$\begin{array}{l}\text { Dominic } \\
\text { Cavendish } \\
19 \text { October } \\
2015 \text { (p. } \\
1044-45)\end{array}$} & $\begin{array}{l}\text { Positive: } \\
\text { "consistently } \\
\text { illuminating" }\end{array}$ & \multirow[t]{2}{*}{$\begin{array}{l}\text { Jane } \\
\text { Shilling } \\
5 \\
\text { August } \\
\text { (2016 } \\
\text { p. } 855)\end{array}$} & $\begin{array}{l}\text { Positive: "a } \\
\text { vivid } \\
\text { reminder of } \\
\text { the piercing } \\
\text { clarity with } \\
\text { which } \\
\text { Chekhov } \\
\text { understood } \\
\text { the human } \\
\text { condition" }\end{array}$ \\
\hline & & $\begin{array}{l}D: 3, W: 2, C: \\
2\end{array}$ & & $\begin{array}{l}\mathrm{D}: 1, \mathrm{~W}: 3, \mathrm{C}: \\
3\end{array}$ & & $\begin{array}{l}D: 2, W: 2, C: \\
8\end{array}$ \\
\hline \multirow[t]{2}{*}{$\begin{array}{l}\text { Evening } \\
\text { Standard }\end{array}$} & \multirow[t]{2}{*}{$\begin{array}{l}\text { Nicholas } \\
\text { de Jongh } \\
18 \text { June } \\
2006 \text { (p. } \\
763-64)\end{array}$} & $\begin{array}{l}\text { Negative: } \\
\text { "maimed" } \\
\text { "pallid } \\
\text { version of } \\
\text { the real } \\
\text { thing" }\end{array}$ & \multirow[t]{2}{*}{$\begin{array}{l}\text { Fiona } \\
\text { Mountford } \\
20 \text { October } \\
2015 \text { (p. } \\
1045-46)\end{array}$} & $\begin{array}{l}\text { Positive: } \\
\text { "brave and } \\
\text { notable } \\
\text { theatrical } \\
\text { achievement } \\
\text { " }\end{array}$ & \multirow[t]{2}{*}{$\begin{array}{l}\text { Henry } \\
\text { Hitchin } \\
\text { gs } \\
4 \\
\text { August } \\
2016 \\
\text { (p. } 853)\end{array}$} & $\begin{array}{l}\text { Positive: } \\
\text { "immensely } \\
\text { rich trilogy" }\end{array}$ \\
\hline & & $\begin{array}{l}D: 5, W: 6, C: \\
10\end{array}$ & & $\begin{array}{l}\text { D: 1, W: 1, C: } \\
4\end{array}$ & & $\begin{array}{l}D: 3, W: 1, C: \\
5\end{array}$ \\
\hline Daily Express & Sheridan & Negative: & Neil & Neutral: & No & \\
\hline
\end{tabular}




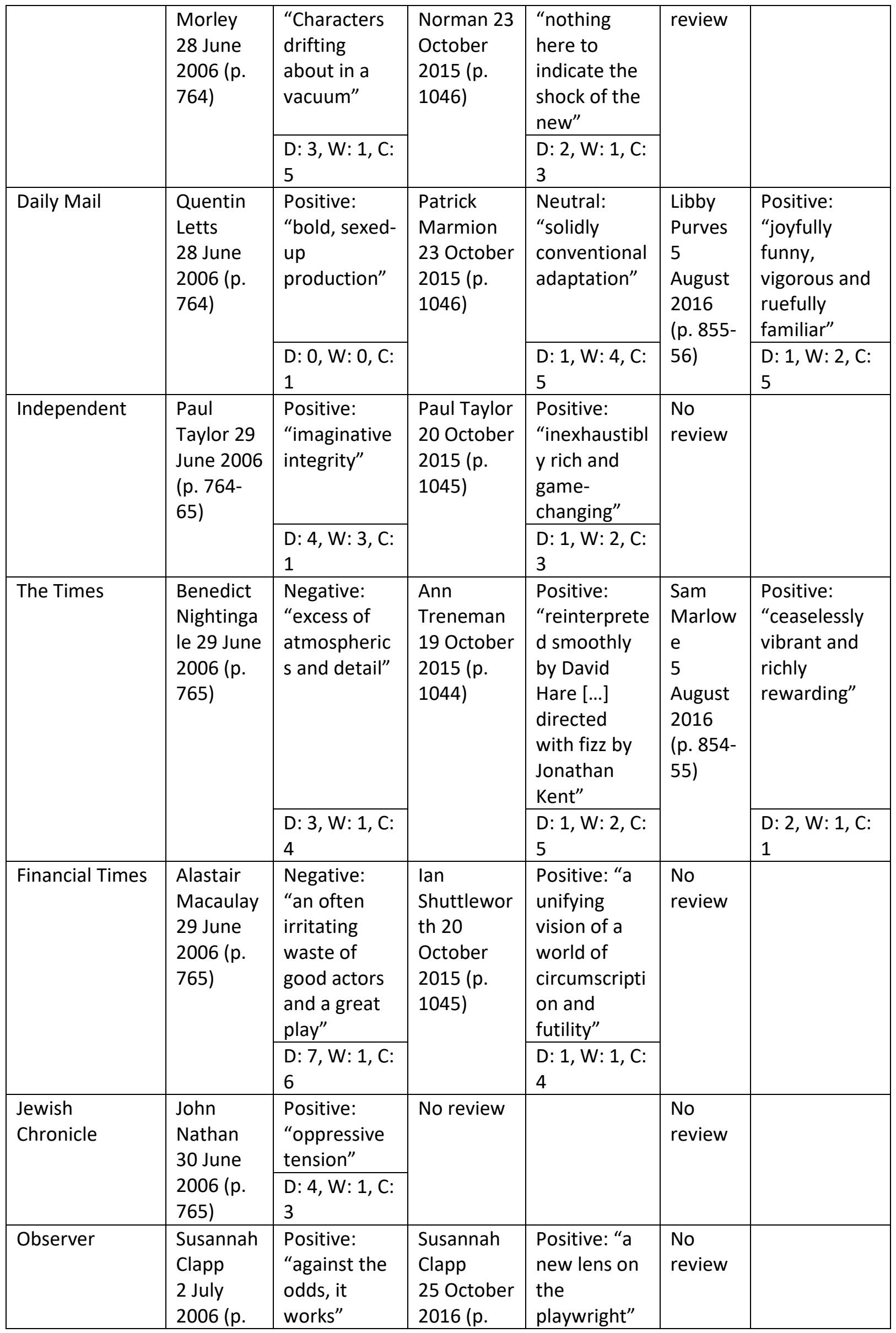




\begin{tabular}{|c|c|c|c|c|c|c|}
\hline & \multirow[t]{2}{*}{$765-66)$} & & \multirow[t]{2}{*}{ 1046-47) } & & & \\
\hline & & $\begin{array}{l}\text { D: 5, W: 1, C: } \\
1\end{array}$ & & $\begin{array}{l}D: 2, W: 3, C: \\
2\end{array}$ & & \\
\hline \multirow[t]{2}{*}{ Sunday Times } & \multirow[t]{2}{*}{$\begin{array}{l}\text { Christoph } \\
\text { er Hart } \\
2 \text { July } \\
2006 \text { (p. } \\
766)\end{array}$} & $\begin{array}{l}\text { Positive: } \\
\text { "motley } \\
\text { ensemble of } \\
\text { squabbling } \\
\text { dysfunctiona } \\
\text { Is" }\end{array}$ & \multirow[t]{2}{*}{$\begin{array}{l}\text { Sarah } \\
\text { Crompton } \\
25 \text { October } \\
2015 \text { (p. } \\
1047)\end{array}$} & $\begin{array}{l}\text { Positive: } \\
\text { "enriching } \\
\text { and } \\
\text { exhilarating } \\
\text { journey" }\end{array}$ & \multirow[t]{2}{*}{$\begin{array}{l}\text { No } \\
\text { review }\end{array}$} & \\
\hline & & $\begin{array}{l}\text { D: 1, W: 1, C: } \\
3\end{array}$ & & $\begin{array}{l}\text { D: 1, W: 2, C: } \\
2\end{array}$ & & \\
\hline \multirow[t]{2}{*}{$\begin{array}{l}\text { Sunday } \\
\text { Telegraph }\end{array}$} & \multirow{2}{*}{$\begin{array}{l}\text { Tim } \\
\text { Walker } \\
2 \text { July } \\
2006 \text { (p. } \\
766)\end{array}$} & $\begin{array}{l}\text { Positive: } \\
\text { "urgent, } \\
\text { compelling" }\end{array}$ & \multirow[t]{2}{*}{ No review } & & \multirow[t]{2}{*}{$\begin{array}{l}\text { No } \\
\text { review }\end{array}$} & \\
\hline & & $\begin{array}{l}\text { D: 1, W: 1, C: } \\
1\end{array}$ & & & & \\
\hline \multirow[t]{2}{*}{$\begin{array}{l}\text { Independent on } \\
\text { Sunday }\end{array}$} & \multirow[t]{2}{*}{$\begin{array}{l}\text { Kate } \\
\text { Bassett } 2 \\
\text { July } 2006 \\
(p, 766)\end{array}$} & $\begin{array}{l}\text { Positive: } \\
\text { "extraordina } \\
\text { ry sense of } \\
\text { fevered } \\
\text { urgency" }\end{array}$ & \multirow[t]{2}{*}{ No review } & & \multirow[t]{2}{*}{$\begin{array}{l}\text { No } \\
\text { review }\end{array}$} & \\
\hline & & $\begin{array}{l}\text { D: 3, W: 1, C: } \\
3\end{array}$ & & & & \\
\hline \multirow[t]{2}{*}{ Sunday Express } & \multirow[t]{2}{*}{$\begin{array}{l}\text { Mark } \\
\text { Shenton } \\
2 \text { July } \\
2006 \text { (p. } \\
766-67)\end{array}$} & $\begin{array}{l}\text { Positive: } \\
\text { "compellingl } \\
\text { y creepy } \\
\text { ambience" }\end{array}$ & \multirow[t]{2}{*}{$\begin{array}{l}\text { Michael } \\
\text { Arditti } \\
25 \text { October } \\
2015 \text { (p. } \\
1047)\end{array}$} & $\begin{array}{l}\text { Positive: } \\
\text { "gloriously } \\
\text { rich and } \\
\text { seamless } \\
\text { undertaking" }\end{array}$ & \multirow[t]{2}{*}{$\begin{array}{l}\text { No } \\
\text { review }\end{array}$} & \\
\hline & & $\begin{array}{l}\text { D: 1. W: 0, C: } \\
1\end{array}$ & & $\begin{array}{l}\text { D: 3, W: 2, C: } \\
3, L: 1\end{array}$ & & \\
\hline \multirow[t]{2}{*}{ Metro (London) } & \multirow[t]{2}{*}{$\begin{array}{l}\text { Clare } \\
\text { Allfree } 28 \\
\text { June } 2006 \\
\text { (p. 767) }\end{array}$} & $\begin{array}{l}\text { Negative: } \\
\text { "jangle of } \\
\text { discordant } \\
\text { notes and } \\
\text { strung-out } \\
\text { nerves" }\end{array}$ & \multirow[t]{2}{*}{ No review } & & \multirow[t]{2}{*}{$\begin{array}{l}\text { No } \\
\text { review }\end{array}$} & \\
\hline & & $\begin{array}{l}\text { D: 6, W: 1, C: } \\
3\end{array}$ & & & & \\
\hline \multirow[t]{2}{*}{ Mail on Sunday } & \multirow[t]{2}{*}{$\begin{array}{l}\text { Georgina } \\
\text { Brown } \\
2 \text { July } \\
2006 \text { (p. } \\
767)\end{array}$} & $\begin{array}{l}\text { Negative: } \\
\text { "some ideas } \\
\text { work, others } \\
\text { feel } \\
\text { laboured" }\end{array}$ & \multirow[t]{2}{*}{ No review } & & \multirow[t]{2}{*}{$\begin{array}{l}\text { Georgin } \\
\text { a } \\
\text { Brown } \\
14 \\
\text { August } \\
2016 \\
\text { (p. } 856)\end{array}$} & $\begin{array}{l}\text { Positive: } \\
\text { "enthralling } \\
\text { attempt [...] } \\
\text { to chart the } \\
\text { evolution of a } \\
\text { dramatic } \\
\text { genius" }\end{array}$ \\
\hline & & $\begin{array}{l}\text { D: 1, W: 2, C: } \\
2\end{array}$ & & & & $\begin{array}{l}\text { D: 2, W: 2, C: } \\
9\end{array}$ \\
\hline $\begin{array}{l}\text { International } \\
\text { Herald Tribune }\end{array}$ & $\begin{array}{l}\text { Matt } \\
\text { Wolf } \\
5 \text { July }\end{array}$ & $\begin{array}{l}\text { Negative: } \\
\text { "takes } \\
\text { reinvigoratio }\end{array}$ & No review & & $\begin{array}{l}\text { No } \\
\text { review }\end{array}$ & \\
\hline
\end{tabular}




\begin{tabular}{|c|c|c|c|c|c|c|}
\hline & $\begin{array}{l}2006(p . \\
767)\end{array}$ & $\begin{array}{l}\mathrm{n} \text { to the } \\
\text { brink and } \\
\text { pushes it } \\
\text { belligerently } \\
\text { over the } \\
\text { edge" } \\
\text { D: } 3, \mathrm{~W}: 1, \mathrm{C}: \\
3\end{array}$ & & & & \\
\hline \multirow[t]{2}{*}{$\begin{array}{l}\text { Time Out } \\
\text { London }\end{array}$} & $\begin{array}{l}\text { Jane } \\
\text { Edwardes } \\
5 \text { July } \\
2006 \text { (p. } \\
767)\end{array}$ & $\begin{array}{l}\text { Negative: } \\
\text { "the } \\
\text { intensity } \\
\text { Mitchell } \\
\text { creates is } \\
\text { frittered } \\
\text { away" }\end{array}$ & No review & & $\begin{array}{l}\text { Andrzej } \\
\text { Lukows } \\
\text { ki } \\
9 \\
\text { August } \\
2016 \\
\text { (p. } 856 \text { ) }\end{array}$ & $\begin{array}{l}\text { Positive: } \\
\text { "seemingly } \\
\text { boundless } \\
\text { depth and } \\
\text { variety } \\
\text { Chekhov } \\
\text { could mine } \\
\text { from his } \\
\text { crumbling } \\
\text { world" }\end{array}$ \\
\hline & & $\begin{array}{l}\text { D: } 2, W: 1, C: \\
2\end{array}$ & & & & $\begin{array}{l}\text { D: 1, W: 3, C: } \\
7\end{array}$ \\
\hline What's On & $\begin{array}{l}\text { Mark } \\
\text { Shenton } \\
6 \text { July } \\
2006 \text { (p. } \\
767)\end{array}$ & $\begin{array}{l}\text { Positive: } \\
\text { "Mitchell } \\
\text { and her fine } \\
\text { ensemble of } \\
\text { actors keep } \\
\text { you gripped" } \\
\text { D: } 2, \text { W: } 1, C: \\
1\end{array}$ & No review & & $\begin{array}{l}\text { No } \\
\text { review }\end{array}$ & \\
\hline $\begin{array}{l}\text { No. of reviews } \\
\text { (positive/negati } \\
\text { ve) }\end{array}$ & 19 & $\begin{array}{l}\text { Positive: } 10 \\
\text { Negative: } 9\end{array}$ & 11 & $\begin{array}{l}\text { Positive: } 9 \\
\text { Neutral: } 2\end{array}$ & 7 & Positive: 7 \\
\hline $\begin{array}{l}\text { Notes: } \\
\text { a) Source: } \\
\text { b) Source: } \\
\text { c) Source: } \\
\text { d) Frequen } \\
\text { (C), liter }\end{array}$ & $\begin{array}{l}\text { heatre Reco } \\
\text { heatre Reco } \\
\text { heatre Reco } \\
\text { y of mentio } \\
\text { translator }\end{array}$ & $\begin{array}{l}d 2006,26: 13, \\
d 201535: 21, k \\
d 2016 \text { 36: 16-1 } \\
\text { s in the review } \\
\text { ). }\end{array}$ & $\begin{array}{l}\text { p. } 763-67 \\
\text { p. } 1043-47 \\
7, \text { pp. } 853-56 \\
\text { or the directo }\end{array}$ & D), writer of $t$ & he version & (W), Chekhov \\
\hline
\end{tabular}

Two factors emerge from the above analysis: positive only just outweighed negative reviews for Crimp's version, whereas Hare's version received no negative reviews. And yet the reason for approval or disapproval in both cases was similar; most of the reviews comment on the new approach of the production, only in Crimp's case the novelty was considered to have gone too far. This is illustrated by Nightingale's dislike of the "excess of atmospherics" 
for The Times in comparison to Nathan's approbation of the "oppressive tension" for the Jewish Chronicle. These reviewers are identifying the same condition, but reacting with opposing emotions. In both cases the innovation was singled out for comment. In Crimp's version, this related to the production values and their integration with the text. Katie Mitchell and the style of her direction were noticeably more commented upon than Jonathan Kent. For Hare, the presentation of three Chekhov plays as a trilogy was considered to have cast fresh light on Chekhov as a playwright.

The second factor to appear is that Chekhov was overwhelmingly named in comparison to the other theatre practitioners. Thus for all their awareness of the craft of translation, adaptation, direction and interpretation, the reviewers were looking past the text and performances back to the original author. This fact could be disillusioning for a researcher in the quest to highlight the role of translation in the transmission of a text from another language, but perhaps it is an example of Boase-Beier's translated text "demanding a different sort of reading from a non-translated text" (2011: 27). These reviewers recognized an urgency and richness of interpretation in both productions, echoing the early responses to the original Russian. Rappaport's literal translation was a key element in generating these reactions.

\section{Conclusion: Reverberations of creativity}

Both of these versions depict Chekhov's play in a new light, albeit with contrasting retellings. Crimp aimed to present the unexpected. Hare placed the play in context. The results of my comparative readings indicate that these are the reactive responses of the writers to the "thick" nuances of Rappaport's translation Rappaport presents the potential shifts and uncertainties of the source text in her literal translation. The writers respond according to their theatrical approaches and collaborative missions. The reviewers failed to remark on the 
translational layers behind the production, but their comments suggest an ability to conduct a reading that acknowledges the multiple voices in the text. The appropriation of the literal translation by these two playwrights with very different artistic profiles provides alternative perspectives of the role of the literal within the translation progression from source to target text, and also demonstrates the proliferation of translation options and strategies emanating from a single source text.

This case study was selected on the basis of my interest and personal experience. The nature of the study, and even the subject, altered as research progressed. I changed the translations that I had chosen to study when I discovered that two translations came from one literal translation. The fact that I could not locate the literal translation for my originally planned subject of study cannot be discounted in my decision. External factors thus affect the progress of case study research as it develops, but researcher-as-subject also plays a part. Saldanha and O'Brien recognize that "ethnological orientation is ... a methodological orientation that can be adopted in case study research," including "a focus on the researcher's personal involvement" (2013: 209). Should I avoid making personal evaluations--which text is better? I know which I prefer, but is that relevant? I hope the information I have provided will provoke a personal responses in the readers of this case study.

Yin's fifth and final criterion for case study research is that the "case study must be composed in an engaging manner" (2009: 189). The idiosyncrasies of the three texts and their authors reflect the personal perspectives of the nature of case study research. The process is necessarily governed by my own interests as researcher, and the serendipitous nature of the availability of research material. Nevertheless, a case study enables a story to "be told more briefly, with greater internal reverberation" (Stake 1995: 135). I trust that the reverberations of this study generate a louder recognition of the strategic value of literal translation within the creative processes of bringing translated work to the stage. 


\section{References}

Anderman, G. (2005) Europe on Stage: Translation and Theatre, London: Oberon Books.

Angelaki, V. (2012) The Plays of Martin Crimp: Making Theatre Strange, Basingstoke:

Palgrave Macmillan.Appiah, K. A. (2012) 'Thick Translation', in Lawrence Venuti (ed) The

Translation Studies Reader (3 ${ }^{\text {rd }}$ edn.), London: Routledge, pp. 331-43.Apollonio, C. and A.

Brintlinger (2012) 'Introduction' in C. Apollonio and A. Brintlinger (eds) Chekhov for the

$21^{\text {st }}$ Century, Bloomington: Slavica, pp. 1-10.

Arts Council England (2016) Expenditure Data: Grant Commitments (Arts Council England, London http://www.artscouncil.org.uk/governance/spending\#section-1) [Accessed $12 / 12 / 2016]$

Billington, M. (2007) State of the Nation: British Theatre since 1945, London: Faber and Faber.

Boase-Beier, J. (2011) A Critical Introduction to Translation Studies, London: Continuum.

Brodie, G. (2012) 'Theatre Translation for Performance: Conflict of Interests, Conflict of Cultures' in B. Maher and R. Wilson (eds) Words, Images and Performances in Translation, London: Continuum, pp. 63-81.

Brodie, G. (2013) ‘Schiller’s Don Carlos in a Version by Mike Poulton, directed by Michael Grandage: The Multiple Names and Voices of Translation' in H. Jansen and A. Wegener (eds) Authorial and Editorial Voices in Translation, Vol. 1, Montréal: Éditions Québécoises de l'Oeuvre, pp. 119-40. 
Brodie, G. (2016a) “'It's Deeper Than That”: Manifestations of Schleiermacher in Martin Crimp's Writing and Translation for Theater' in T. Seruya and J.M. Justo (eds) Rereading Schleiermacher: Translation, Cognition and Culture, Berlin: Springer, pp. 233-44.

Brodie, G. (2016b) ‘The Sweetheart Factor: Tracing Translation in Martin Crimp's Writing for Theatre', Journal of Adaptation in Film and Performance 9.1: 83-96.

Brodie, G. (2018) The Translator on Stage, New York: Bloomsbury

Chichester Festival Theatre (2015) Young Chekhov: The Birth of a Genius [Theatre Programme] Chichester: Chichester Festival Theatre.

Clayton J.D. and Y. Meerzon (2013) 'Introduction: The Text and its Mutations: On the Objectives of the Volume' in J.D. Clayton and Y. Meerzon (eds) Adapting Chekhov: The Text and its Mutations, New York: Routledge, pp. 1-11.

Crimp, M. (2006) Anton Chekhov: The Seagull, London: Faber and Faber.

Frayn, M. (2006) Anton Chekhov: Plays, London: Bloomsbury.

Hampton, C. (2007) Anton Chekhov: The Seagull, London: Faber and Faber.

Hare, D. (2015) Anton Chekhov: Young Chekhov: Platonov, Ivanov, The Seagull, London: Faber and Faber.

Hare. D. (2016) How I Learned to Love Adaptation (The Guardian, London https://www.theguardian.com/stage/2016/jan/23/davidhareadaptationsthemasterbuilderchekh ovoldvic) [accessed 23/9/2016].

Hermans, T. (2007) The Conference of the Tongues, Manchester: St. Jerome.

Holdsworth, N. (2010) Theatre and Nation, Basingstoke: Palgrave Macmillan. 
Jackson, L. (2017) 'Forces at Work: Euripides' Medea at the National Theatre 2014' in G. Brodie and E. Cole (eds) Adapting Translation for the Stage, Abingdon: Routledge, pp. 10417.

Marsh, C. (2010a) 'Chekhov, Anton' in D. Kennedy (ed) The Oxford Companion to Theatre and Performance, Oxford: Oxford University Press, pp. 111-12.

Marsh, C. (2010b) 'Stanislavsky, Konstantin’ in D. Kennedy (ed) The Oxford Companion to Theatre and Performance, Oxford: Oxford University Press, pp. 572-73.

Megson, C. and D. Rebellato (2007) “"Theatre and Anti-theatre”: David Hare and Public Speaking' in R. Boon (ed) The Cambridge Companion to David Hare, Cambridge:

Cambridge University Press, pp. 236-49.

Merlin, B. (2003) Konstantin Stanislavsky, London: Routledge.

Middeke, M. (2011) 'Martin Crimp', in M. Middeke, P. P. Schnierer and A. Sierz (eds) The Methuen Drama Guide to Contemporary British Playwrights, London: Methuen, pp. 82-102.

Mitchell, K. (2009) The Director's Craft: A Handbook for the Theatre, Abingdon: Routledge.

Munday, J. (2010) 'Evaluation and Intervention in Translation' in M. Baker, M. Olohan and M. C. Pérez (eds) Text and Context. Essays on Translation and Interpreting in Honour of Ian Mason, Manchester: St Jerome, pp. 77-94.

National Theatre (2006) The Seagull [Theatre Programme], London: Royal National Theatre.

National Theatre (2016) Mark Strong and Hope Davis Lead the Cast of 'The Red Barn', a New Play by David Hare (Royal National Theatre, London https://www.nationaltheatre.org.uk/sites/default/files/the_red_barn_-_press_release.pdf) [accessed 28/11/2016]. 
National Theatre Archive (2016) Welcome to the National Theatre Archive (Royal National Theatre, London http://catalogue.nationaltheatre.org.uk/CalmView/Default.aspx?) [accessed 6/12/2016].

Peräkylä, A. and J. Ruusuvuori (2011) 'Analyzing Talk and Text' in N.K. Denzin and Y. S. Lincoln (eds) The Sage Handbook of Qualitative Research, Thousand Oaks: Sage, pp. 529543.

Peace, R. (1993) 'Chekhov into English: The Case of The Seagull' in P. Miles (ed) Chekhov on the British Stage, Cambridge: Cambridge University Press, pp. 216-25.

Postlewait, T. (2010) 'Mise-en-scène' in D. Kennedy (ed) The Oxford Companion to Theatre and Performance, Oxford: Oxford University Press, p. 396.

Rappaport, H. (2001) 'Lost in Translation: The too-often Unsung Work of the Literal Translator', The Author 112: 176-77.

Rappaport, H. (2006) Anton Chekhov: The Seagull, London: Royal National Theatre (unpublished).

Rappaport, H. (2007) 'Chekhov in the Theatre: The Role of the Translator in New Versions' in G. Anderman (ed) Voices in Translation: Bridging Cultural Divides, Clevedon: Multilingual Matters, pp. 66-77.

Saldanha, G. and S. O’Brien (2013) Research Methodologies in Translation Studies, Manchester: St. Jerome.

Sierz, A. (2013) The Theatre of Martin Crimp (2nd edn.), London: Bloomsbury.

Stake, R.E. (1995) The Art of Case Study Research, Thousand Oaks: Sage. 
Trencsényi, K. (2015) Dramaturgy in the Making: A User's Guide for Theatre Practitioners, London: Bloomsbury.

Turner, C. (2007) 'Hare in Collaboration: Writing dialogues' in R. Boon (ed) The Cambridge Companion to David Hare, Cambridge: Cambridge University Press, pp. 109-22.

Victoria and Albert Museum (2016) Theatre and Performance Archives (Victoria and Albert Museum, London http://www.vam.ac.uk/content/articles/t/archives-theatre-performance/) [accessed 12/11/2016].

Young, S. (2009) 'Making the “unstageable” stageable: English rewritings of Chekhov's first play', Modern Drama 52.3: 325-50

Yin, R. K. (2009) Case Study Research: Design and Methods (4 ${ }^{\text {th }}$ edn.), Thousand Oaks: Sage.

\footnotetext{
'The Arts Council England grant commitment to the Royal National Theatre for 2016-17 Quarter 2 was $£ 17,217,000$. This made the National Theatre the fourth highest recipient, preceded by the Royal Opera House $(£ 24,772,000)$; the National Foundation for Youth Music $(£ 19,302,000)$; and the Southbank Centre (£19,186,000) (Arts Council England, 2016).

ii Each Act of Rappaport's literal translation begins with new page numbering at 1.
} 